It is difficult, if one keeps an open mind, to avoid thinking that all the major groups had an exceedingly remote and perhaps more or less contemporaneous origin, and that the geological record, as at present known, reflects variations in the kinds of plants which grew in localities where preservation was possible and, to some extent, the successive dominance of different groups. The fact that no Angiosperms are known from the Palæozoic surely does not mean, in view of their diversity in the Mesozoic, that they did not exist then, but that they did not happen to be preserved. Even now, when they are the dominant group, the great majority of them perish without trace.

Dr. Alfred Gundersen, like Dr. J. Hutchinson before him, has, however, taken the view that it is possible to make out relationships between the different orders of flowering plants. He has provided more material for those who like arguing about such things, and he is to be congratulated on going outside the traditional limits of systematics by taking into account most of the attributes of plants in framing his classification. In brief introductory chapters experts deal with such topies as wood anatomy, cytotaxonomy and plant geography, and these fertures are used in the accounts of families which form the main bulk of the work.

This book, like the recent one by Dr. Hutchinson, performs a valuable service in stressing the fact that some of the main criteria in traditional classifications, for example, the distinction between Archichlamydeæ and Metachlamydeæ, are largely matters of convenience. But from the practical point of view convenience is a great merit in a classification, and from the prevailing lack of evidence it would seem that the time is not yet ripe, if indeed it can ever become ripe, for the abandonment of the old systems, though they may with advantage be modified to a limited extent.

So far as the origin of species is concerned, we have travelled a considerable distance since the time of Darwin ; but very fow new facts about the origin of orders have come to light, and we may agree more whole-heartedly than ever with the statement that "the origin of flowering plants is an abominable mystery".

T. G. TUTIN

\section{GROWING-UP IN SCHOOL}

Studies in the Social Psychology of Adolescence By J. E. Richardson, J. F. Forrester, J. K. Shukla and P. J. Higginbotham. (International Library of Sociology and Social Reconstruction.) Pp. $\mathrm{x}+266$. (London: Routledge and Kegan Paul, Ltd., 1951.) 21s. net.

IN the past four decades, adolescence has had a good press. Novelists, playwrights, educationists, psychologists, psychiatrists, preachers and magistrates have described the hopes and fears, the wayward and steadfast conduct, of the 'teen-ager', and the cult of youth has led to spectacular results, at times catastrophic. But whereas half a century ago writers could assert, perhaps a little smugly, that growing up necessarily involves a period of storm and stress, to-day many people ask how far these disturbances are caused by mental or bodily factors incidental to maturation, and how far the barriers which the adolescent tries to respect or surmount with different degrees of success have been erected by society.
One result has been to stimulate inquiry into the structure of extant societies in which growing-up is less painful than in the European or American communities upon which the majority of social studies have been focused. Are there groups without a well-marked period of adolescence?

In one sense, conflicts appear adolescent only if the causal factors in the situation are envisaged by adults. Teen-agers are men and women if required for National Service, but not if they wish to vote in elections.

Study has recently been directed upon adolescence from new directions. Psychoanalysis and its derivatives, social anthropology, sociometry, and the qualitative investigations of the relations between small groups are examples. Study of group tensions is important, for the adolescent often exhibits ambivalent behaviour towards his elders. Even his maleness is usually exhibited in ways which are canalized by the social structure in which he lives. Types of misbehaviour and the labels given to them may reflect his social or economic status. While to-day co-operation is urged in many quarters, and teamgames encouraged or enforced in schools, pupils may still regard their intellectual work as private and personal. In this section of the school-world man is an island unto himself. How, otherwise, could he reasonably be certain of a scholarship to the universities? What bright essayist in a school would want to pool his best ideas with a discussion-group ? But this is a rhetorical question. The answer, so far as one school is concerned, is given in the present book.

Adults, whose school success was undoubted, sometimes admit that they liked a subject, not only for itself, but also because of friendly relations in the group which studied it. Some confess that it was the teacher they really liked, and believe that a change of teacher might have had results damaging or beneficial.

Problems like these, until recently the subject of speculation and anecdote, have boen studied by the authors. Using methods derived from Moreno and Lewin, they have investigated the life of school pupils. They have tested, for example, the possibility of improving English composition by free group discussion. Under ordinary class-room discipline, not only does one pupil speak at a time, but also the teacher's eye has to be caught, and some mental mechanisms, not all of them pathological, render a fow children too 'shy' to try this feat.

Adolescent attitudes towards religion and elders were examined. An interesting question arises, whether the standard text-books reporting a general adolescent tendency to revolt against parental opinion have not been based upon the United States, where, on the whole, the parents expect it. In Britain some children take this attitude, whereas others feel there may be something in what parents say. But are there types of attitude, depending upon early relations towards one or both parents?

One reason for carrying out this investigation, which concentrates more upon results than upon theory, is that it would help teachers to know the mental pictures which boys and girls have of themselves. What are their respective levels of aspiration, and do they think they can achieve them? Or have they long ago, in an attempt to be realistic, lowered their sights?

As the authors fully acknowledge, some of the methods used raise problems of their own. But since children learn in groups, it is good that group relations should be better understood. 